\title{
Notes on two crabs (Crustacea, Brachyura, Dynomenidae and Iphiculidae) collected from red coral beds in northern Taiwan, including a new species of Pariphiculus Alcock, 1896
}

\author{
Peter K. L. Ng', M.-S. Jeng ${ }^{2}$ \\ I Lee Kong Chian Natural History Museum, Faculty of Science, National University of Singapore, 2 Conser- \\ vatory Drive, Singapore 117377, Republic of Singapore 2 Biodiversity Research Center, Academia Sinica, 128 \\ Academia Road, Section 2, Nankang, Taipei 11529, Taiwan, R.O.C. \\ Corresponding author: Peter K. L. Ng (peterng@nus.edu.sg)
}

Academic editor: S. De Grave | Received 4 July 2017 | Accepted 6 August 2017 | Published 29 August 2017

http://zoobank.org/C6FB5FE4-A6F0-47A4-AFBA-3ABC59350D07

Citation: Ng PKL, Jeng M-S (2017) Notes on two crabs (Crustacea, Brachyura, Dynomenidae and Iphiculidae) collected from red coral beds in northern Taiwan, including a new species of Pariphiculus Alcock, 1896. ZooKeys 694: 135-156. https://doi.org/10.3897/zookeys.694.14871

\begin{abstract}
Two brachyuran species of the families Dynonemidae and Iphiculidae are reported from red coral beds in northern Taiwan. The dynonemid Acanthodromia margarita (Alcock, 1899) has hitherto been reported from the Andaman Sea, Japan, and Philippines and the species is here recorded for the first time from Taiwan. A new species of iphiculid, Pariphiculus stellatus sp. n., is also described. The new Pariphiculus, which also occurs in the Philippines, is superficially similar to $P$. agariciferus Ihle, 1918, a species known from Indonesia, Japan, Philippines, South China Sea, Taiwan, and Vanuatu, but can be distinguished by distinct carapace, pleonal and male first gonopod features.
\end{abstract}

\section{Keywords}

Brachyuran crab, Dromioidea, East China Sea, Leucosioidea, new Pariphiculus species, taxonomy

\section{Introduction}

The small seamount associated with Peng-Chia-Yu Island, a small outcrop $60 \mathrm{~km}$ northeast of Keelung in Taiwan, is a special area with controlled commercial fishing for precious red corals (MOJ 2014). One endemic new species, Corallium carusrubrum

Copyright Peter K. L.Ng, M.-S. Jeng. This is an open access article distributed under the terms of the Creative Commons Attribution License (CC BY 4.0), which permits unrestricted use, distribution, and reproduction in any medium, provided the original author and source are credited. 
Tu, Dai \& Jeng, 2012 (Anthozoa: Octocorallia: Coralliidae) was recently described from this site.

Recently, two crab species were obtained from the area where the precious red corals are collected. One is the rarely reported dromioid Acanthodromia margarita (Alcock, 1899) (Dynomenidae), hitherto reported from India, Japan, and Philippines. The second is a new species of leucosioid of the genus Pariphiculus Alcock, 1896 (Iphiculidae), which is superficially similar to P. agariciferus Ihle, 1918, from Indonesia, Japan, Philippines, South China Sea, Taiwan, and Vanuatu. The taxonomy of these two species is discussed. The new species of Pariphiculus, here named $P$. stellatus, is described and compared at length with P. agariciferus. Pariphiculus stellatus sp. $\mathrm{n}$. is also reported from the Philippines.

\section{Materials and methods}

The measurements provided (in millimetres) are of the maximum carapace width and length (including spines), respectively. The abbreviations G1 and G2 are used for the male first and second gonopods, respectively.

Specimens examined are deposited in the collections of the Institute of Zoology, Biodiversity Research Center, Academia Sinica (ASIZ), Taipei, Taiwan; Muséum national d'Histoire naturelle (MNHN), Paris, France; and the Zoological Reference Collection (ZRC) of the Lee Kong Chian Natural History Museum, National University of Singapore. The terminology used follows that in Tan and $\mathrm{Ng}$ (1995) and Davie et al. (2015).

\section{Systematics}

\section{Family Dynomenidae Ortmann, 1892}

Genus Acanthodromia A. Milne-Edwards, 1880

\section{Acanthodromia margarita (Alcock, 1899)}

Figs 1A-C, 2, 3

Dynomene margarita Alcock, 1899: 19, pl. 2: fig. 3.

Acanthodromia margarita - Alcock 1900: 134; Sakai 1965: 43; Sakai 1976: 31, pl. 7: fig. 2; Nagai 1989: 43; McLay 1999: 539, fig. 31; Marumura and Kosaka 2003: 20; McLay and Ng 2005: 18, fig. 5; Ng et al. 2008: 37.

Material examined. Taiwan: 1 female $(17.8 \times 18.3 \mathrm{~mm})$ (ASIZ 75484), waters of Zone A (precious coral fishing ground), Peng-Chia-Yu Island, $60 \mathrm{~km}$ northeast of Keelung, $25^{\circ} 37.901^{\prime} \mathrm{N}, 122^{\circ} 28.577^{\prime} \mathrm{E}, 175 \mathrm{~m}$, Taiwan, coll. Fishing Vessel "De-Cheng 136", M.-L. Chang, 14 May 2017. Philippines: 1 male $(14.7 \times 17.7$ mm) (ZRC 2001.358), Balicasag Island, 200-300 m, coll. December 2000; 1 male 


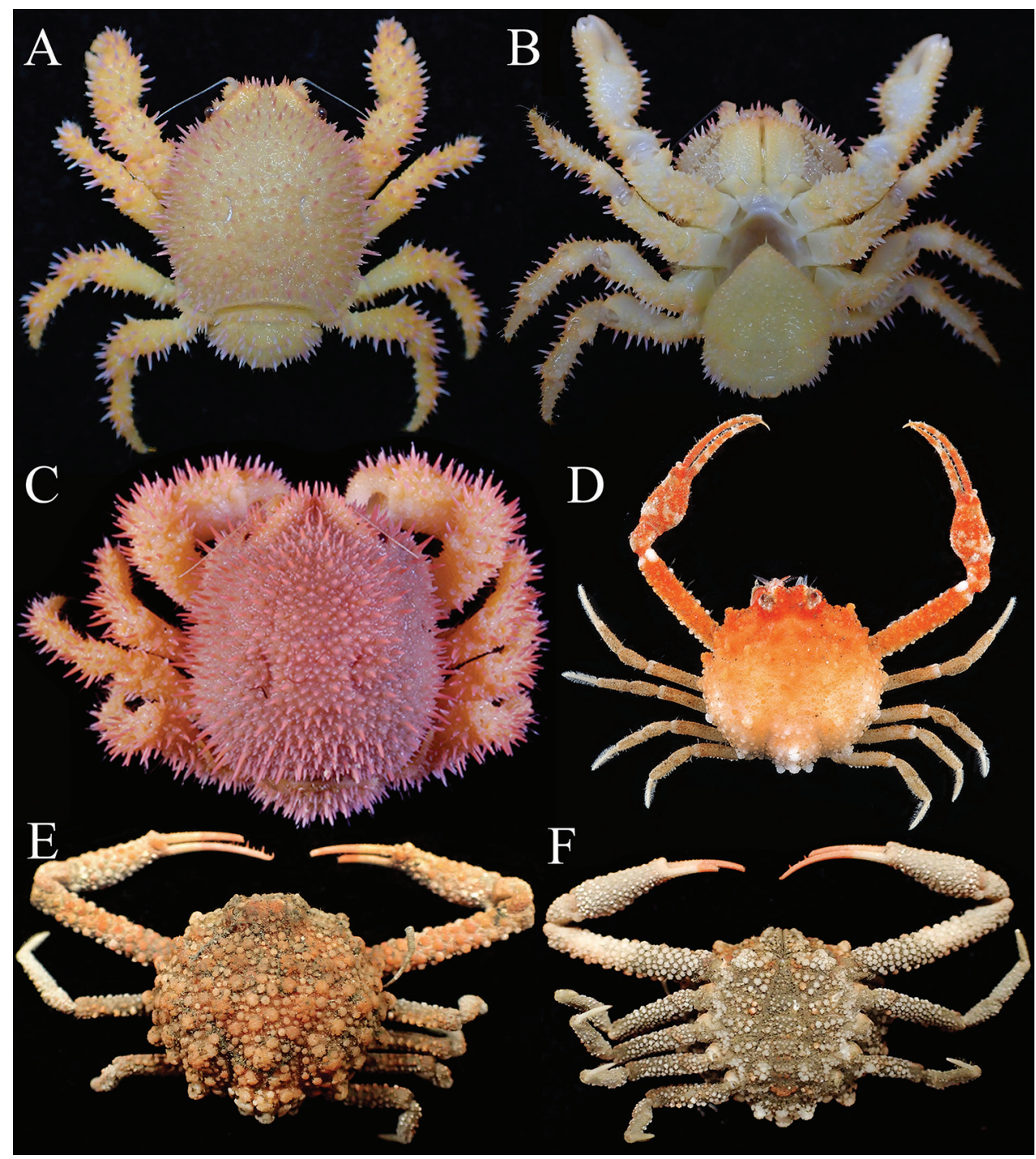

Figure I. Colour in life. A, B Acanthodromia margarita (Alcock, 1899), female $(17.8 \times 18.3 \mathrm{~mm})$ (ASIZ 75484), Taiwan C Acanthodromia margarita (Alcock, 1899), female (17.7 × $19.2 \mathrm{~mm})($ ZRC 2008.1420), Philippines D Pariphiculus agariciferus, Ihle, 1918, male $(11.9 \times 12.1 \mathrm{~mm})($ ZRC 2009.471), Vanuatu E, F Pariphiculus stellatus sp. n., holotype male $(27.7 \times 24.5 \mathrm{~mm}$ ) (ASIZ 75485), Taiwan. A, C, D, E overall dorsal view; $\mathbf{B}, \mathbf{F}$ ventral view.

$(10.5 \times 11.5 \mathrm{~mm}), 2$ females $(7.8 \times 8.3 \mathrm{~mm}, 11.2 \times 12.2 \mathrm{~mm}), 2$ ovigerous females $(14.7 \times 16.7 \mathrm{~mm}, 17.0 \times 18.5 \mathrm{~mm})(\mathrm{ZRC} 2003.668), 1$ male $(9.9 \times 10.6 \mathrm{~mm})$, 1 female $(12.3 \times 13.4 \mathrm{~mm})(\mathrm{MNHN})$; Balicasag Island, $200-300 \mathrm{~m}, 25-30 \mathrm{Jul}$ 2003; 1 male $(14.7 \times 15.8 \mathrm{~mm})($ ZRC 2008.1425), station PN1, Balicasag Island, 


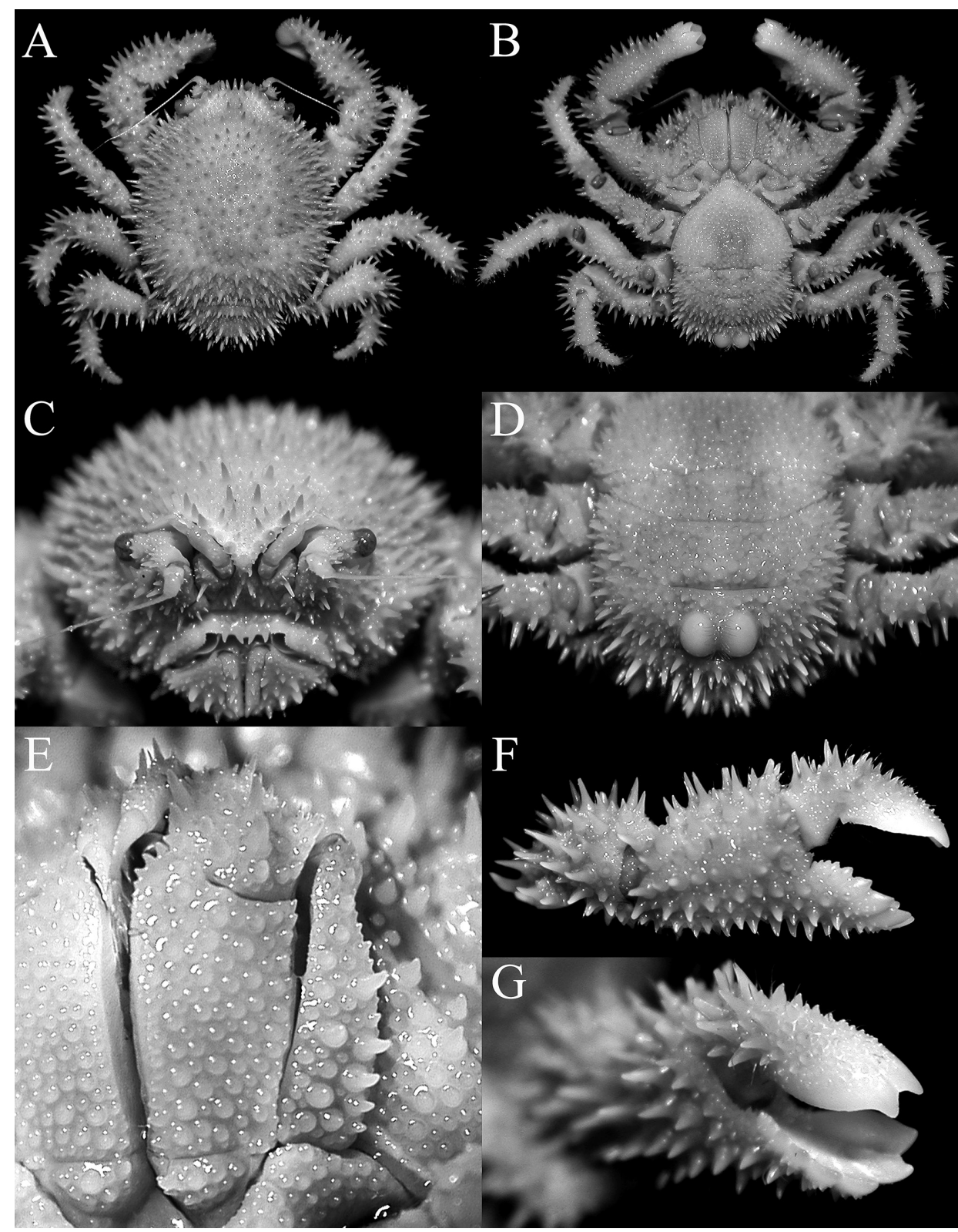

Figure 2. Acanthodromia margarita (Alcock, 1899), female $(17.8 \times 18.3 \mathrm{~mm})$ (ASIZ 75484), Taiwan. $\mathbf{A}$ overall dorsal view $\mathbf{B}$ ventral view of cephalothorax $\mathbf{C}$ frontal view of cephalothorax $\mathbf{D}$ pleon showing tubercles on somite $4 \mathbf{E}$ outer view of left third maxilliped $\mathbf{F}$ outer view of right chela $\mathbf{G}$ sublateral view of fingers of right chela.

200-300 m, coll. November 2003; 1 female (no pereopods left, $11.2 \times 12.0 \mathrm{~mm}$ ) (ZRC 2008.1426), Balicasag Island, 200-300m, coll. November 2003-April 2004; 1 male $(15.3 \times 16.7 \mathrm{~mm})($ ZRC 2008.1419), station PN1, Balicasag Island, coll. 


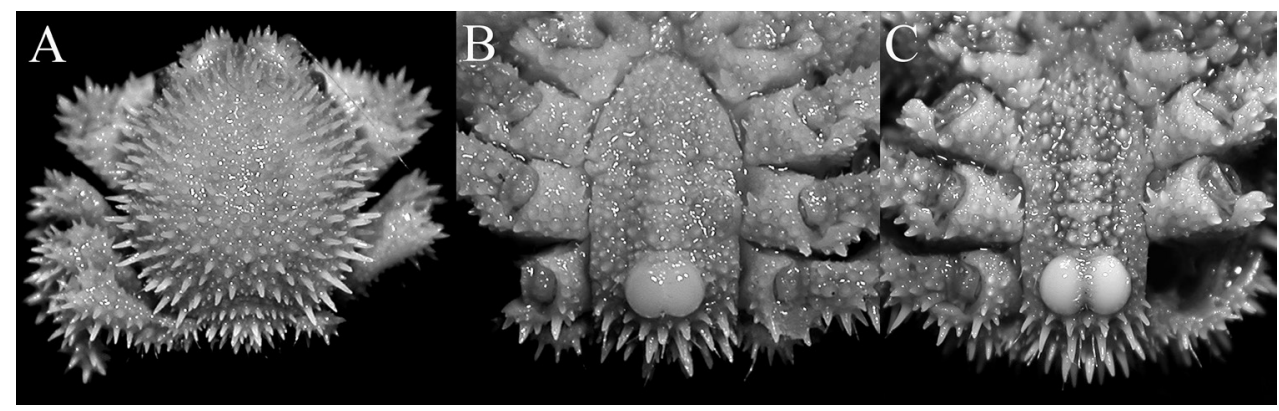

Figure 3. Acanthodromia margarita (Alcock, 1899). A, B male $(11.6 \times 12.0 \mathrm{~mm})($ ZRC 2003.668), Philippines C, male (13.5 × $14.2 \mathrm{~mm}$ ) (ZRC 2004.596), Philippines. A overall dorsal view B, C pleon showing tubercles on somite 4 .

29 May 2004; 1 female $(17.7 \times 19.2 \mathrm{~mm})$ (ZRC 2008.1420), Balicasag Island, coll. 29 March 2004; 5 males $(8.8 \times 10.6 \mathrm{~mm}, 11.2 \times 12.5 \mathrm{~mm}, 11.3 \times 13.0 \mathrm{~mm}, 13.5 \times$ $14.2 \mathrm{~mm}, 14.1 \times 16.2 \mathrm{~mm}), 2$ females $(15.4 \times 17.2 \mathrm{~mm}, 15.8 \times 17.0 \mathrm{~mm}), 1$ female (carapace cracked) (ZRC 2004.596), Balicasag Island, coll. 2 March 2004; 1 male (11.3 $\times 12.7 \mathrm{~mm}$ ) (ZRC 2008.1043), Balicasag Island, coll. May 2004 [all above locations at 9.518891 ${ }^{\circ} \mathrm{N}, 123.680511^{\circ} \mathrm{E}$, Panglao, Bohol, Visayas, Philippines; purchased from local shell fishermen, obtained by tangle nets]; 1 male $(13.9 \times 15.3 \mathrm{~mm}), 2$ females $(14.2$ $\times 15.0 \mathrm{~mm}, 15.7 \times 16.1 \mathrm{~mm})($ ZRC 2013.372), Maribojoc Bay, Panglao, Bohol, Philippines, coll. J. Arbasto, 30 May 2004; 1 female $(14.2 \times 15.0 \mathrm{~mm})($ ZRC 2007.207), Maribojoc Bay, Panglao, Bohol, Philippines, coll. J. Arbasto, July-May 2005.

Description. Colour. McLay and Ng (2005: 18) described the fresh colour of Philippine specimens as "light pink spines on carapace and the pereopods with golden yellow dactyli". The present Taiwan specimen is orange-yellow on all its dorsal surfaces, with the spines orange-pink with white tips (Fig. 1A, B). In some Philippine specimens, the carapace can be a more striking pink and the pereopods orange-yellow with the spines pink (Fig. 1C).

Remarks. The present female specimen from Taiwan is one of the largest on record and agrees well with published descriptions and figures of the species. The frontal margin appears to vary in form due to the relative strength of the frontal spines, particularly the median pseudorostral one. The two large rounded, basally fused tubercles on pleonal somite 4 is distinct in both sexes; with those in some of the smaller specimens appearing almost completely fused, forming one structure (Fig. 3B). The posterior margin of the epistome always has four spines, but the structure of the two median ones varies slightly, from directly pointing downwards (e.g., McLay and Ng 2005: fig. 5B) to curving medially (Fig. 2C).

Distribution and depth. Acanthodromia margarita was described from the Andaman Sea in the eastern Indian Ocean, and has been also reported from Japan, Philippines, and now Taiwan. The Indian Ocean specimen was from relatively shallow water (135 m), but the series from the Philippines was from 120-300 m depth. The present Taiwan specimen was collected from a depth of $175 \mathrm{~m}$. 


\section{Family IPHICULIDAE Alcock, 1896 \\ Pariphiculus Alcock, 1896}

\section{Pariphiculus stellatus sp. $\mathbf{n}$.}

http://zoobank.org/7EC3869E-1F27-4C50-8EE3-DCEB4817630C

Figs $7-10,11 \mathrm{~B}, \mathrm{D}, \mathrm{F}, 12 \mathrm{~B}, \mathrm{D}, \mathrm{F}, 13 \mathrm{E}-\mathrm{H}$

Pariphiculus sp. - Ikeda 1998: 84, pl. 2.

Pariphiculus agariciferus - Galil and Ng 2007: 87 (part) (not Pariphiculus agariciferus Ihle, 1918).

Material examined. Holotype: male $(27.7 \times 24.5 \mathrm{~mm})$ (ASIZ 75485), waters of Zone A (precious coral fishing ground), Peng-Chia-Yu Islands, $60 \mathrm{~km}$ northeast of Keelung city, $25^{\circ} 37.765^{\prime} \mathrm{N}, 122^{\circ} 28.623^{\prime} \mathrm{E}, 170 \mathrm{~m}$, Taiwan, coll. Fishing Vessel "De-Cheng 136", M.-L. Chang, 7 May 2017. Philippines: Non-types: 1 female $(31.1 \times 26.2 \mathrm{~mm})$ (ZRC 2017.188), Balicasag Island, coll. J. Arbasto, July 2004-May 2005; 1 male (24.3 $\times 21.6 \mathrm{~mm}), 1$ female $(35.1 \times 29.6 \mathrm{~mm})($ ZRC 2007.590), Balicasag Island, coll. 2 March 2004; 1 male $(15.4 \times 13.8 \mathrm{~mm})$ (ZRC 2017.184), station PN1, Balicasag Island, coll. November 2003; 1 female $(32.3 \times 27.6 \mathrm{~mm})$ (ZRC 2017.185), Balicasag Island, Panglao, Philippines, $80-140 \mathrm{~m}$, in tangle nets, coll. March 2004 [all above locations at $9.518891^{\circ} \mathrm{N}, 123.680511^{\circ} \mathrm{E}$, Panglao, Bohol, Visayas, Philippines; purchased from local shell fishermen, obtained by tangle nets].

Comparative material of Pariphiculus agariciferus Ihle, 1918. Taiwan: 1 male $(12.9 \times 12.3 \mathrm{~mm})\left(\right.$ ASIZ 75113), 22 $2^{\circ} 14.74^{\prime} \mathrm{N}, 118^{\circ} 43.69^{\prime} \mathrm{E} 141 \mathrm{~m}$, southern Taiwan, coll. M.-L. Chang, 14 May 2011. Philippines: 1 male $(16.6 \times 16.2 \mathrm{~mm})($ ZRC 2015.436), Balicasag Island, coll. J. Arbasto, July 2004-May 2005; 2 females (19.5 × $18.9 \mathrm{~mm}, 19.8 \times 18.9 \mathrm{~mm}$ ) (ZRC 2017.181), Balicasag Island, coll. J. Arbasto, 2006; 1 female (19.3 × $17.6 \mathrm{~mm}), 1$ broken female (ZRC 2001.559), Balicasag Island, 50-500 m, coll. 28 November 2001; 1 male $(14.4 \times 13.3 \mathrm{~mm}), 1$ female $(21.0 \times 19.1 \mathrm{~mm})$ (ZRC 2009.297), Balicasag Island, coll. June 2002; 2 males $(13.4 \times 13.3 \mathrm{~mm}, 15.8$ $\times 15.8 \mathrm{~mm}), 1$ female $(19.5 \times 18.4 \mathrm{~mm})($ ZRC 2007.588a), station PN1, Balicasag Island, coll. November 2003; 1 male $(13.9 \times 13.3 \mathrm{~mm})($ ZRC 2009.1164), Balicasag Island, coll. December 2003; 1 female $(16.6 \times 18.6 \mathrm{~mm})($ ZRC 2017.180), station P2, Balicasag Island, 2004; 1 male $(14.0 \times 13.5 \mathrm{~mm})$ (ZRC 2015.437), Balicasag Island, coll. 2 March 2004; 1 male $(15.8 \times 15.0 \mathrm{~mm})$ (ZRC 2017.187), Balicasag Island, Panglao, Philippines, 80-140 m, in tangle nets, coll. March 2004; 1 male (15.5 $\times 14.4 \mathrm{~mm})($ ZRC 2012.484), Balicasag Island, coll. May 2004; 1 female $(22.0 \times 21.6$ $\mathrm{mm}$ ) (ZRC 2017.183), station P1, Balicasag Island, coll. 6 July 2004; 1 young female $(15.0 \times 14.7 \mathrm{~mm})($ ZRC 2017.182), station P4, Balicasag Island, coll. 2 July 2004; 2 females $(18.4 \times 18.0 \mathrm{~mm}, 22.1 \times 21.3 \mathrm{~mm})$ (ZRC 2009.288), Balicasag Island, coll. J. Arbasto, July 2004-May 2005; 1 male $(12.8 \times 13.7 \mathrm{~mm}), 1$ female $(19.0 \times 19.0 \mathrm{~mm})$ (ZRC 2017.186), Balicasag Island, Panglao, Philippines, $80-140 \mathrm{~m}$, in tangle nets, coll. J. Arbasto, 2004-2005; 1 male $(15.4 \times 16.0 \mathrm{~mm})($ ZRC 2009.185), Balicasag 

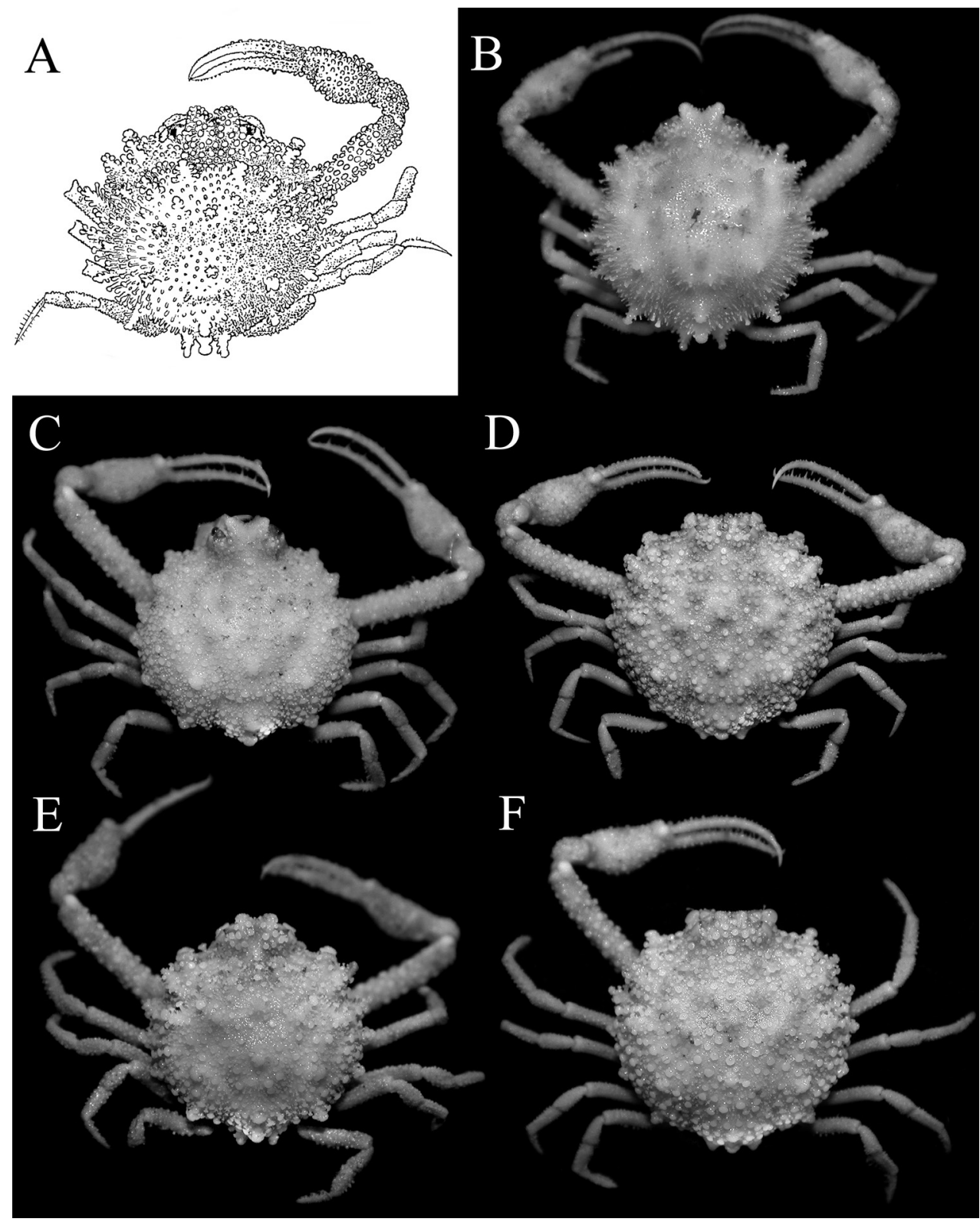

Figure 4. Pariphiculus agariciferus Ihle, 1918, overall dorsal view. A holotype male $(9.0 \times 9.3 \mathrm{~mm})$, after Ihle (1918: fig. 230) B young male $(10.2 \times 9.6 \mathrm{~mm})$ (ZRC 2009.470), Vanuatu C male $(11.9 \times 12.1 \mathrm{~mm})$ (ZRC 2009.471), Vanuatu D female $(22.1 \times 21.3 \mathrm{~mm})$ (ZRC 2009.288), Philippines E male $(15.5 \times$ $14.4 \mathrm{~mm})($ ZRC 2012.484), Philippines F female $(19.0 \times 19.0 \mathrm{~mm})($ ZRC 2017.186), Philippines.

Island, 120-160 m, coll. J. Arbasto, January-December 2007 [all above locations at 9.518891 ${ }^{\circ} \mathrm{N}, 123.680511^{\circ} \mathrm{E}$, Panglao, Bohol, Visayas, Philippines; purchased from local shell fishermen, obtained by tangle nets]; 1 male $(17.2 \times 16.9 \mathrm{~mm}), 2$ females $(16.1$ 


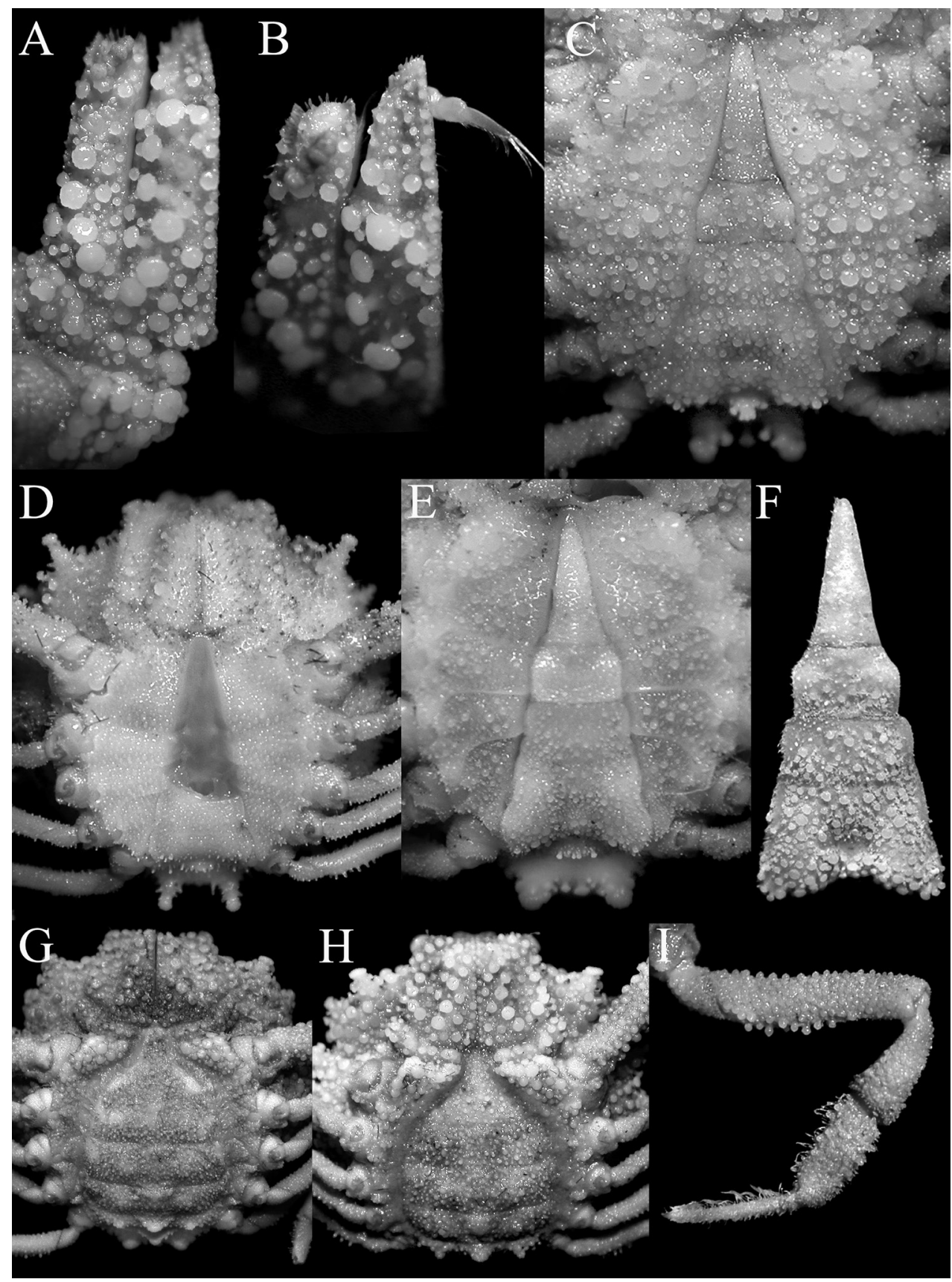

Figure 5. Pariphiculus agariciferus Ihle, 1918. A, B female $(19.8 \times 18.9 \mathrm{~mm})($ ZRC 2017.181), Philippines $\mathbf{C}$ male $(15.5 \times 14.4 \mathrm{~mm})$ (ZRC 2012.484), Philippines $\mathbf{D}$ young male $(10.2 \times 9.6 \mathrm{~mm})$ (ZRC 2009.470), Vanuatu E male $(11.9 \times 12.1 \mathrm{~mm})$ (ZRC 2009.471), Vanuatu F male $(15.8 \times 15.0 \mathrm{~mm})$ (ZRC 2017.187), Philippines G, I female $(22.1 \times 21.3 \mathrm{~mm}$ ) (ZRC 2009.288), Philippines $\mathbf{H}$ female $(19.0 \times 19.0 \mathrm{~mm})($ ZRC 2017.186), Philippines. A, B outer view of right third maxilliped C-E male thoracic sternum and pleon $\mathbf{E}$ female thoracic sternum and pleon $\mathbf{G}, \mathbf{H}$ female thoracic sternum and pleon $\mathbf{E}$ female thoracic sternum and pleon $\mathbf{I}$ right fourth ambulatory leg. 


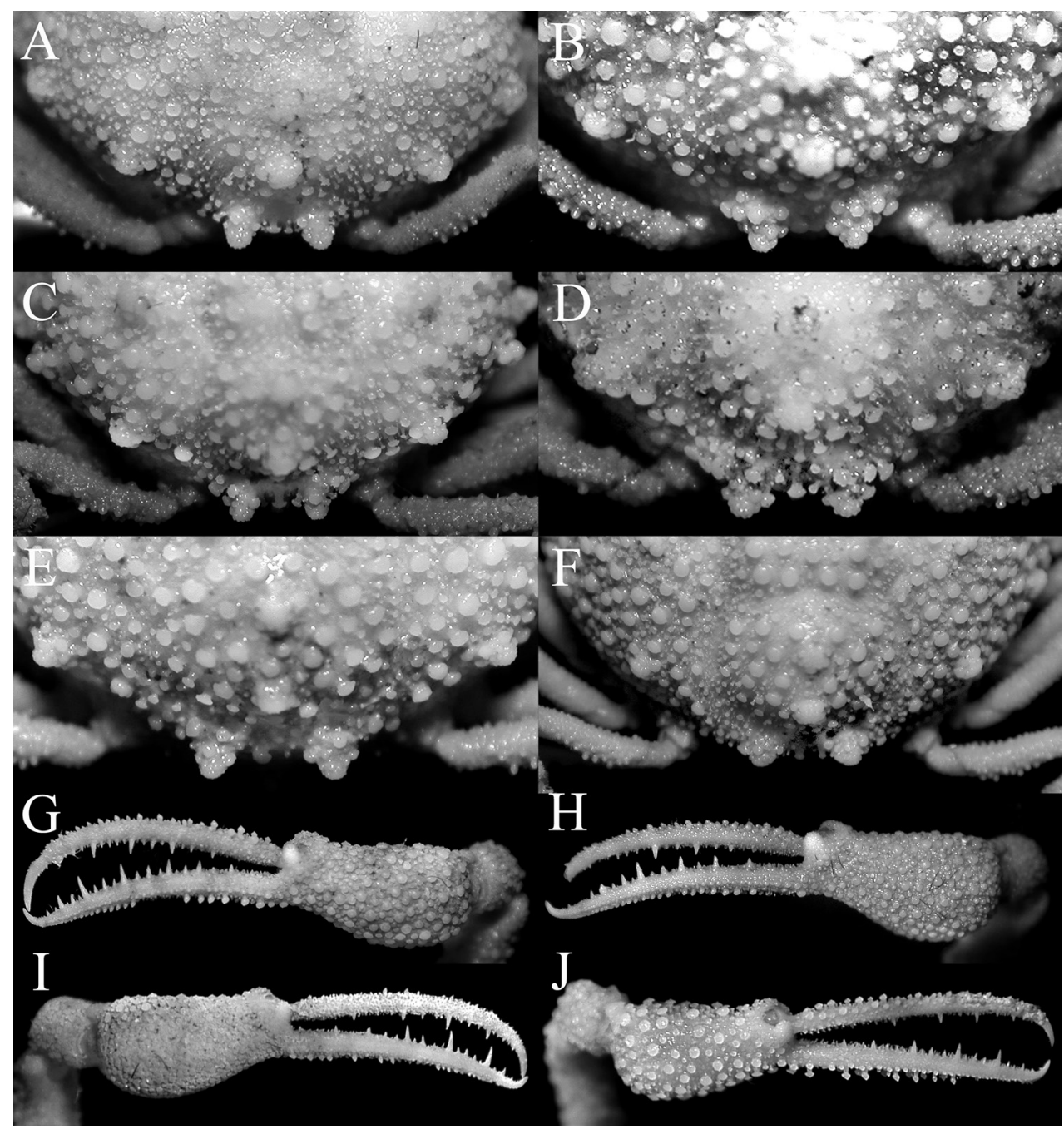

Figure 6. Pariphiculus agariciferus Ihle, 1918. A male $(11.9 \times 12.1 \mathrm{~mm})($ ZRC 2009.471), Vanuatu B male $(15.8 \times 15.0 \mathrm{~mm})($ ZRC 2017.187), Philippines C, J male $(15.5 \times 14.4 \mathrm{~mm})($ ZRC 2012.484), Philippines $\mathbf{D}$ male $(12.8 \times 13.7 \mathrm{~mm})($ ZRC 2017.186), Philippines E, G female $(19.0 \times 19.0 \mathrm{~mm})($ ZRC 2017.186), Philippines $\mathbf{F}, \mathbf{H}$ female $(22.1 \times 21.3 \mathrm{~mm})$ (ZRC 2009.288), Philippines I male $(11.9 \times 12.1$ $\mathrm{mm}$ ) (ZRC 2009.471), Vanuatu. A-F intestinal region and posterior margin of carapace $\mathbf{G}, \mathbf{H}$ outer view of left chela $\mathbf{I}$, J outer view of right chela.

$\times 15.4 \mathrm{~mm}, 18.5 \times 18.7 \mathrm{~mm})($ ZRC 2013.104), Maribojoc Bay, Panglao, Bohol, Philippines, coll. J. Arbasto, November 2003-April 2004. Vanuatu: 1 male $(10.2 \times 9.6 \mathrm{~mm})$, 1 female $(13.0 \times 13.5 \mathrm{~mm})($ ZRC 2009.470), station AT13, south of Aésé Island, Palikulu Bay, $15^{\circ} 27.8$ S $167^{\circ} 15.7 \mathrm{E}, 146-153 \mathrm{~m}$, Santo, coll. N.O."Alis", SANTO Expedition, 19 September 2006; 1 male $(11.9 \times 12.1 \mathrm{~mm})($ ZRC 2009.471), station AT61, south of Urélapa Island, West Malo Island, $15^{\circ} 39^{\prime} \mathrm{S} 167^{\circ} 01^{\prime} \mathrm{E}, 266-281 \mathrm{~m}$, Santo, coll. N.O."Alis", SANTO Expedition, 4 October 2006; 2 juvenile females $(10.3 \times 9.4 \mathrm{~mm}$, $13.4 \times 13.6 \mathrm{~mm}), 1$ carapace only $(17.9 \times 17.4 \mathrm{~mm})($ ZRC 2009.472), station AT63, 
south of Urélapa Island, West Malo Island, 15\%40'S 16701'E, 290-334 m, Santo, coll. N.O."Alis", SANTO Expedition, 4 October 2006; 1 male $(11.9 \times 11.8 \mathrm{~mm})($ ZRC 2009.473), station AT64, south of Urélapa Island, West Malo Island, $15^{\circ} 40^{\prime} \mathrm{S} 167^{\circ} 02^{\prime} \mathrm{E}$, 249-252 m, Santo, coll. N.O."Alis", SANTO Expedition, 19 September 2006.

Diagnosis. Carapace 1.12-1.19 times broader than long; with relatively low mushroom-shaped tubercles on carapace, chelipeds and ambulatory legs with margins of tops distinctly asteriform (Figs 7, 8A, G, 9A, B, 11D, F, 12B); gastric and branchial regions inflated (Figs $8 \mathrm{~A}, \mathrm{G}, 11 \mathrm{D}, \mathrm{F}$ ); in lateral view, surface behind postfrontal region gently concave, forming shallow depression (Fig. 11F); suborbital tubercle relatively low, not protruding (Figs 8A, G, 9C, 11D); palms of chelae relatively long, slender, with fingers long, gently curved (Figs 9E-H, 12F); dorsal margin of dactylus and ventral margin of pollex of chela lined with low granules, never serrated (Figs 9E-H, 12F); tubercles and granules on surface of male and female pleons relatively large, tend to be fused, forming semi-eroded structures (Figs 8D, E, 9D, 12D); male telson proportionately shorter (Figs 8D, E, 12D); G1 relatively long, slender (Fig. 13E).

Description of male. Carapace 1.12-1.19 times broader than long, regions not well-defined; dorsal surface with numerous low mushroom-shaped tubercles and granules, edges of raised tubercle with short slender spinules, asteriform from dorsal view, with scattered short setae between them; postfrontal region raised, prominent; surface behind postfrontal region with shallow depression; gastric regions convex, separated from swollen branchial regions by shallow, partially granulated groove; branchial regions with numerous large and small tubercles, separated from intestinal and cardiac regions by relatively broad granulated groove; cardiac and intestinal regions barely distinguishable, intestinal region with 2 prominent large tubercles, one dorsal in position, another directed obliquely posteriorly; hepatic region gently concave, with distinct low lateral tubercle, surface granulated; pterygostomial and suborbital regions with numerous mushroom-shaped, asteriform tubercles; branchiostegite region with numerous low, rounded tubercles (Figs 7, 8A, G, 9A-C, 11B, D-F, 12B). posterolateral border adjacent to cardiac region prominently protruded to form large tooth. Front slightly produced, not protruding beyond anterior edge of buccal cavity and closed third maxillipeds, gently upturned, weakly bilobed (distinct in frontal view) (Figs 7 , $8 \mathrm{~A}, \mathrm{G}, 11 \mathrm{~B}, \mathrm{D}, 12 \mathrm{~B})$. Antero- and posterolateral margins not cristate, not clearly demarcated, with structures gradually merging medially on carapace; subdorsal margins lined with numerous large mushroom-shaped tubercles with asteriform tops, with interspersed smaller granules of similar form; posterior carapace margin with 3 broad, stout tubercles, each covered with smaller granules, median one smallest (Figs 7, 9A, B, 11B, 12B).

Basal article of antenna subquadrate, surface gently convex, fused with epistome; short flagellum lodged in orbital hiatus (Fig. 9C). Basal segment of antennule occupies entire fossa when closed, with folded articles hidden behind basal article; margins of fossae almost smooth (Figs 8A, G, 9C). Orbit rounded; eyes small with short ocular peduncle, mobile; suborbital tubercle relatively low, not prominent, asteriform (Figs 8A, G, 9C, 11D). 


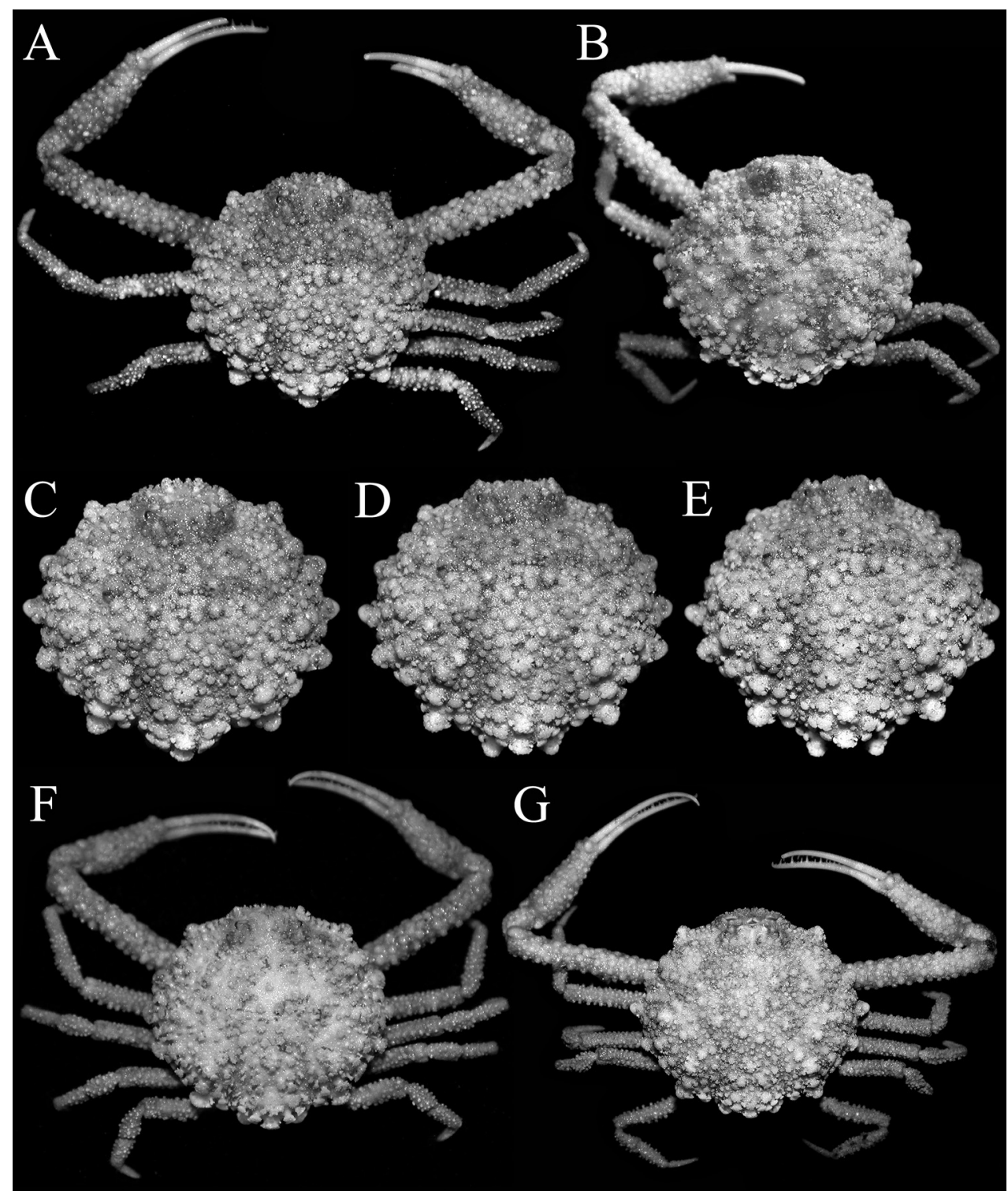

Figure 7. Pariphiculus stellatus sp. n. A, C-E holotype male $(27.7 \times 24.5 \mathrm{~mm})$ (ASIZ 75485), Taiwan B female $(32.3 \times 27.6 \mathrm{~mm})($ ZRC 2017.185), Philippines $\mathbf{F}$ male $(24.3 \times 21.6 \mathrm{~mm})($ ZRC 2007.590), Philippines G female $(35.1 \times 29.6 \mathrm{~mm})$ (ZRC 2007.590), Philippines. A, B, F, G overall dorsal view C-E dorsal view of carapace photographed from slightly different angles.

Third maxillipeds relatively short; outer surfaces of merus, ischium, basis and exopod densely covered with mushroom-shaped tubercles and granules, many with asteriform tops; merus triangular with broadly pointed apex, inner edge straight, outer edge gently convex, with large, low rounded tubercle on proximal margin; ischium ca. 


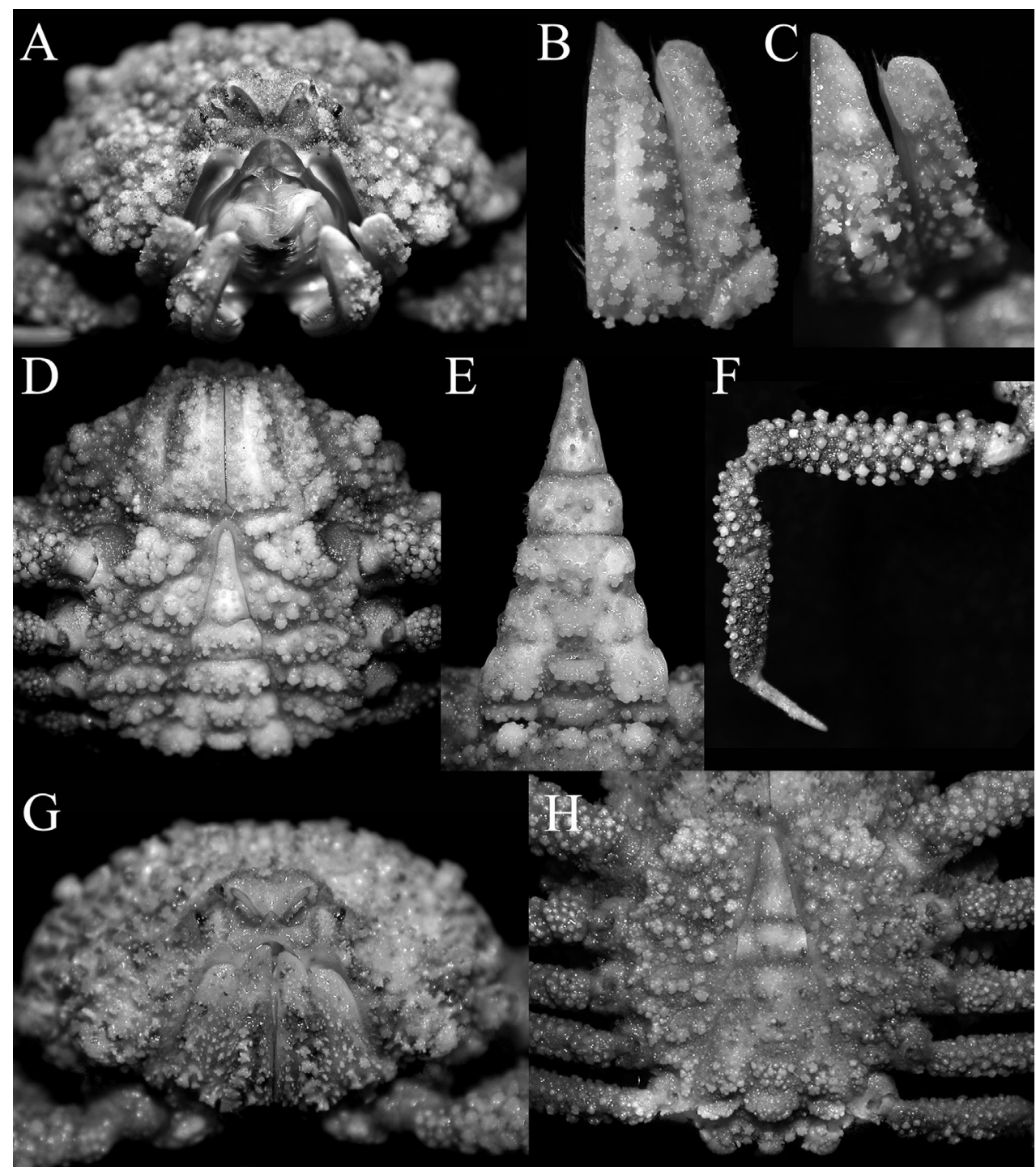

Figure 8. Pariphiculus stellatus sp. n. A-F holotype male $(27.7 \times 24.5 \mathrm{~mm})$ (ASIZ 75485), Taiwan G, $\mathbf{H}$ male $(24.3 \times 21.6 \mathrm{~mm})$ (ZRC 2007.590), Philippines. A, G frontal view of cephalothorax showing orbit, antennae, antennules and buccal cavity B, C outer view of left third maxilliped $\mathbf{D}, \mathbf{H}$ male thoracic sternum and pleon $\mathbf{E}$ male pleon $\mathbf{F}$ left third ambulatory leg.

2 times longer than merus along inner margin, with prominent submedian ridge of tubercles; palp (carpus, propodus and dactylus, short, completely hidden behind ischium when folded; exopod relatively broad, reaching beyond distal margin of ischium, tip rounded, without flagellum (Figs 8B, C, G 11D).

Chelipeds slender, elongate, subequal; surfaces with numerous large, round or low mushroom-shaped tubercles, some with asteriform tops (Figs 7A, F, G, 9E-H, 11B, 12F). 


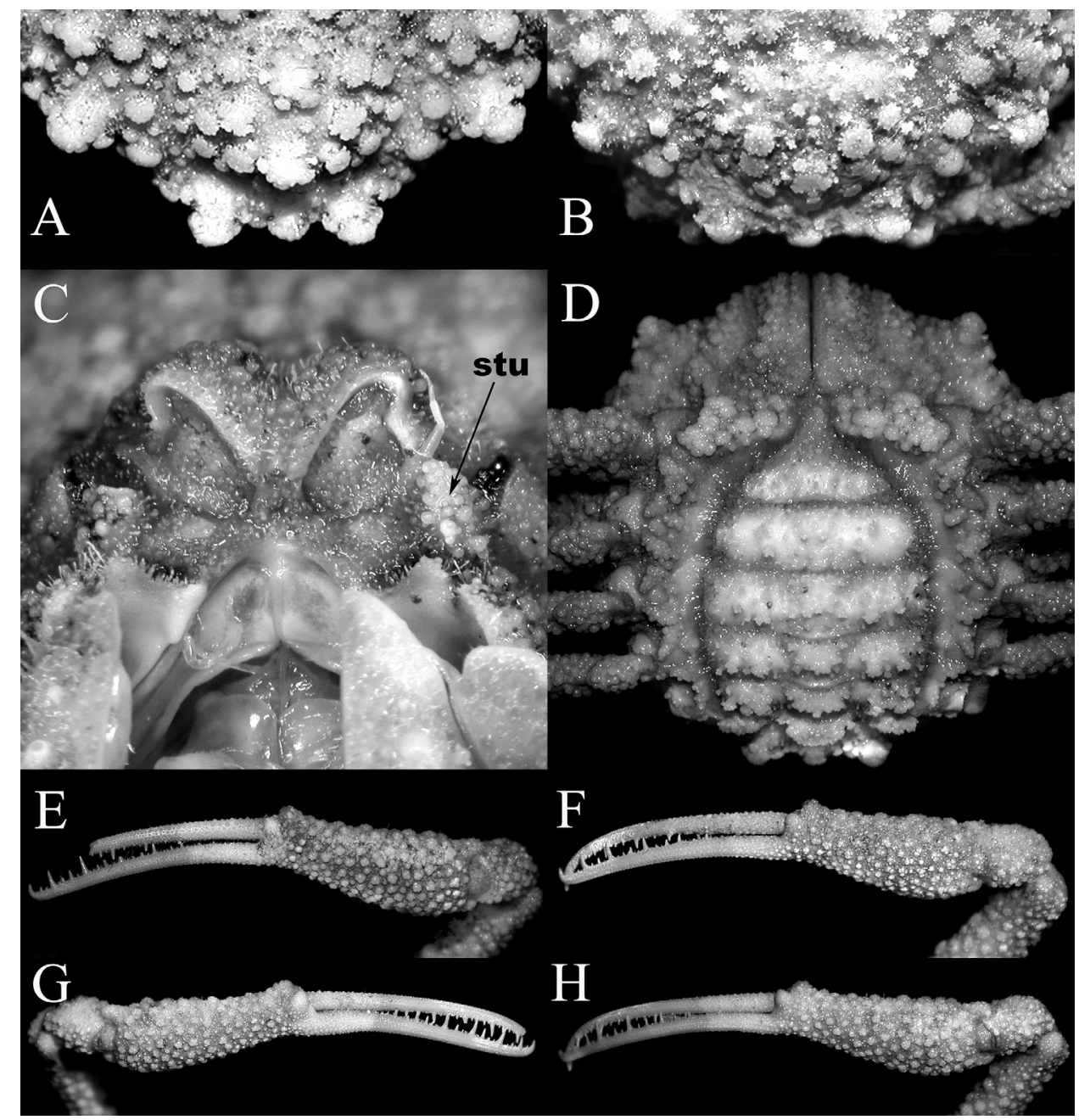

Figure 9. Pariphiculus stellatus sp. n. A, C, E holotype male $(27.7 \times 24.5 \mathrm{~mm})$ (ASIZ 75485), Taiwan B female $(32.3 \times 27.6 \mathrm{~mm})($ ZRC 2017.185), Philippines F male $(24.3 \times 21.6 \mathrm{~mm})($ ZRC 2007.590), Philippines D, G, H female (35.1 × $29.6 \mathrm{~mm})($ ZRC 2007.590), Philippines. A, B intestinal region and posterior margin of carapace $\mathbf{C}$ antennae, antennules and orbit $\mathbf{D}$ female thoracic sternum and pleon $\mathbf{E}, \mathbf{F}, \mathbf{H}$ outer view of left chela $\mathbf{G}$ outer view of right chela. Abbreviation: stu = suborbital tubercle.

Merus cylindrical in cross-section; carpus small, subtriangular (Figs 7A, F, G, 9E-H, 11B). Chela with proximal half relatively stouter, gradually tapering to more slender distal part, margins granulated but not serrated; fingers elongate, just longer than palm, surface with very small granules, gently curved, distal two-thirds more darkly pigmented, rest of structure white in preservative; cutting edges of both fingers with long and short sharp vertical spines (Figs 9E-H, 12F).

Ambulatory legs relatively short, first leg longest; surfaces of merus, carpus and propodus covered with small rounded or mushroom-shaped tubercles, some with 


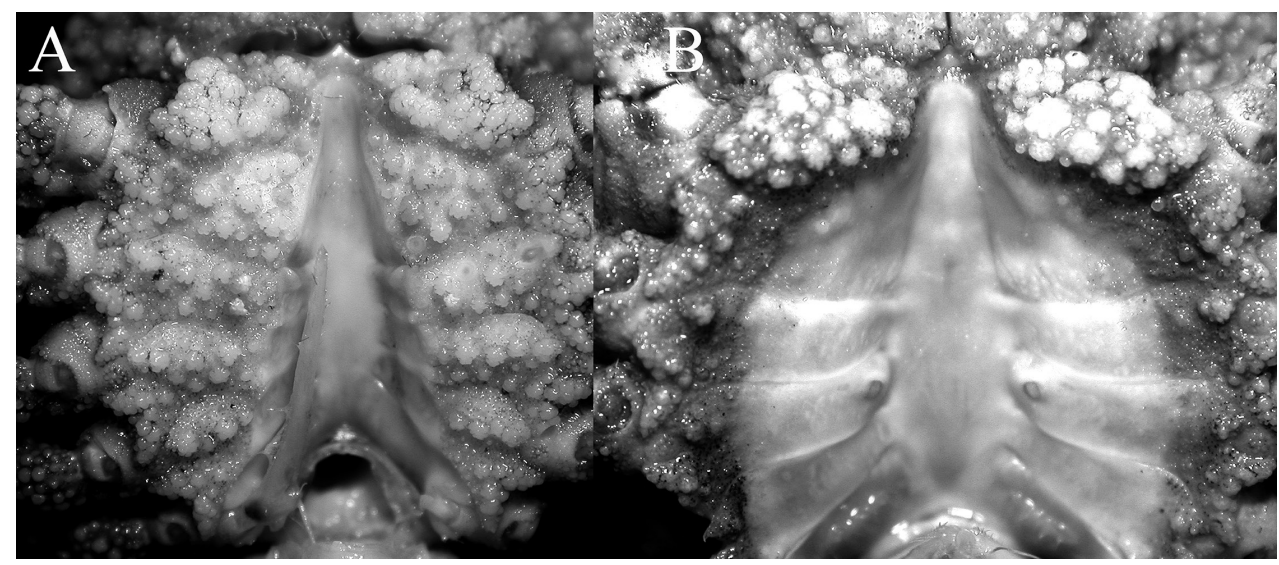

Figure 10. Pariphiculus stellatus sp. n. A holotype male $(27.7 \times 24.5 \mathrm{~mm})$ (ASIZ 75485), Taiwan B female $(31.1 \times 26.2 \mathrm{~mm})($ ZRC 2017.188), Philippines. A male sternopleonal cavity showing right G1 and pleonal locking tubercle on sternite 5 B female sternopleonal cavity showing vulvae on sternite 6 .

asteriform tops (Figs 7A, F, G, 8F, 11B); dactylus styliform, almost straight, surfaces smooth, margins lined with setae (Fig. 8F).

Thoracic sternum relatively narrow transversely; surfaces of sternites $1-4$ covered with round or low mushroom-shaped tubercles, some with asteriform tops, some coalescing to form ridges and clusters; surfaces of sternites 5-8 with more individual tubercles and granules; sternites 1 and 2 separated by low ridge, longitudinally very narrow, lateral surfaces of sternite 2 with thick row of coalesced tubercles; separated from coalesced row of tubercles on sternite 3 by deep groove; tubercles on sternite 3 separated from cluster of coalesced tubercles on sternite 4 by deep groove; sternites otherwise not clearly demarcated; small part of sternite 8 just visible when pleon closed; sternopleonal cavity narrow, deep, nearly reaching buccal cavity at level of sternite 2 (Figs $8 \mathrm{D}, \mathrm{H}, 12 \mathrm{D}$ ); all sutures from sternites 3-8 medially interrupted; peg-like tubercle of pleonal locking mechanism relatively large, semicircular, directed anteriorly (Fig. 10A); penis short, tubular with dilated tip, arising from condyle of coxa of fourth ambulatory leg (Fig. 10A).

Pleon triangular, covered with large rounded tubercles, many coalescing to form semi-eroded structure on somites 1-6; surface of telson with scattered small, narrow mushroom-shaped; somites 1, 2 free; somites 3-5 functionally fused although somites can still be approximately distinguished; somites 2-6 trapezoidal; somite 6 free, broadly subrectangular with lateral margin convex; telson triangular, elongate; surface of somite 3 with subrectangular cluster of fused granules; surface of somite 2 with 3 uneven clusters of fused granules (Figs 8D, E, H, 12D).

G1 ca. 2 times length of G2, relatively slender, slightly sinuous basally, becoming almost straight distally; margins lined with dense soft long setae; tip sharp (Fig. 13E-G). G2 with with elongate subpetaloid terminal process which is slightly shorter than basal segment (Fig. 13H). 


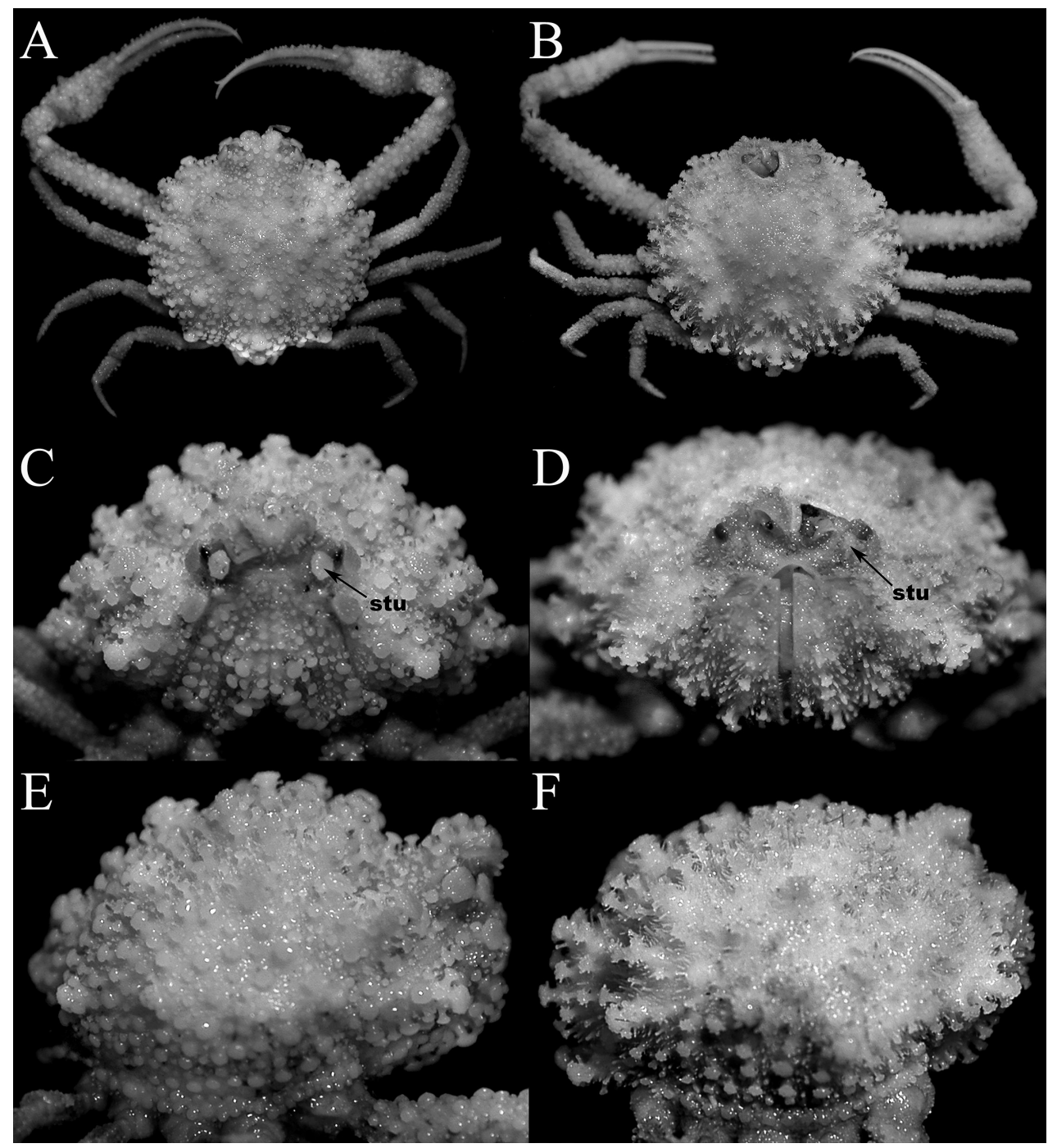

Figure I I. Comparisons between similar sized Pariphiculus agariciferus Ihle, 1918, and P. stellatus sp. n. A, C, E P. agariciferus, male $(15.8 \times 15.8 \mathrm{~mm})$ (ZRC 2007.588), Philippines B, D, F P. stellatus, male $(15.4 \times 13.8 \mathrm{~mm})($ ZRC 2017.184), Philippines [left frontal margin damaged]. A, B overall dorsal view C, $\mathbf{D}$ frontal view of cephalothorax showing orbit, antennae, antennules and buccal cavity $\mathbf{E}, \mathbf{F}$ right lateral view of cephalothorax. Abbreviation: stu = suborbital tubercle.

Females and variations. Female specimens are similar to males in almost all nonsexual aspects. The female pleon is of the typical iphiculid condition, with all the somites and telson freely articulating, none swollen or forming a dome-like structure covering the egg mass (Fig. 9D). The vulva is relatively small and simple with around opening, covered by an operculum, and directed obliquely posteriorly (Fig. 10B). 


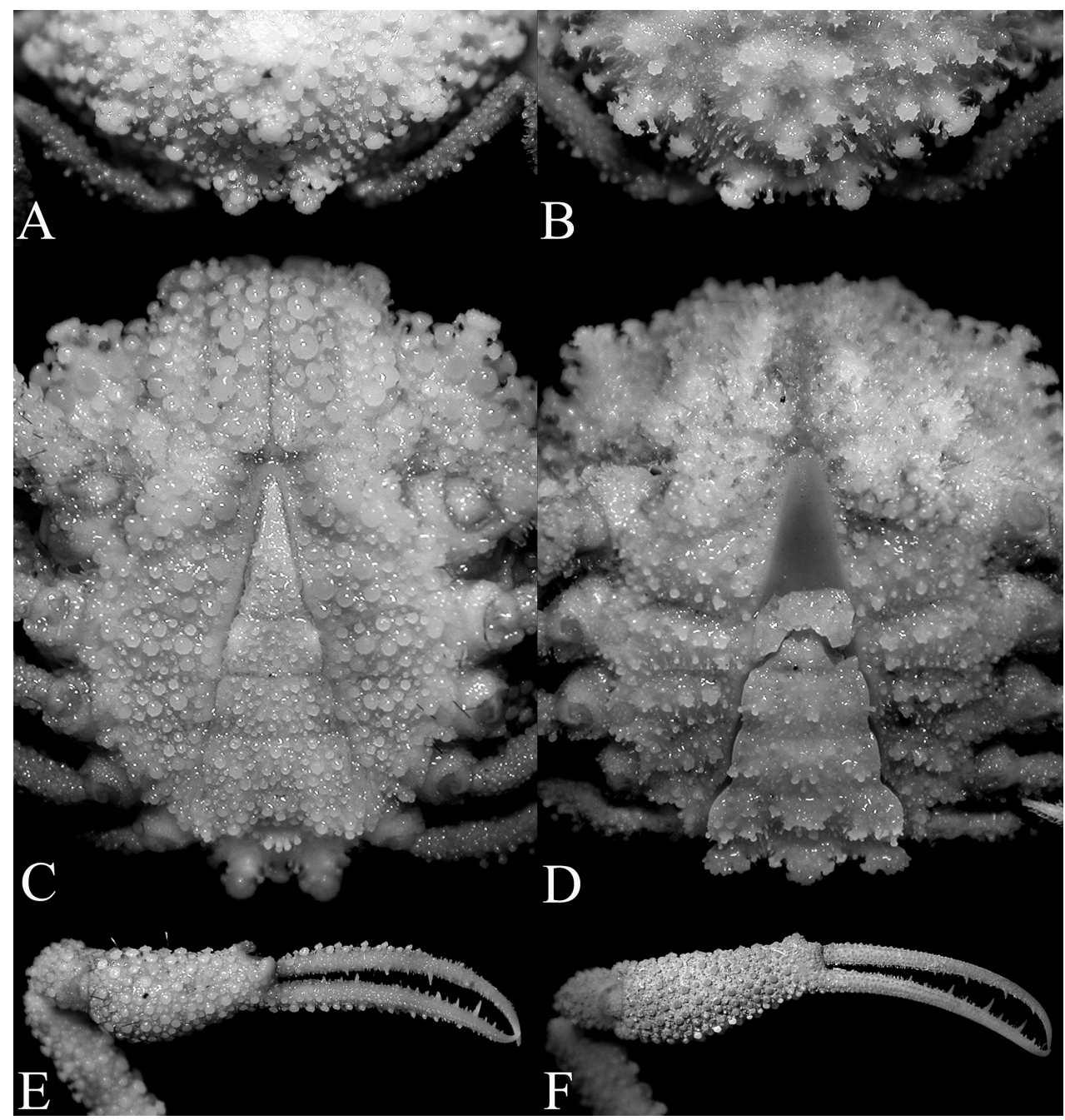

Figure I2. Comparisons between similar sized Pariphiculus agariciferus Ihle, 1918, and P. stellatus sp. n. A, C, E P. agariciferus, male $(15.8 \times 15.8 \mathrm{~mm})$ (ZRC 2007.588), Philippines B, D, F P. stellatus, male $(15.4 \times$ $13.8 \mathrm{~mm}$ ) (ZRC 2017.184), Philippines [telson missing, approximate shape and proportions as indicated by space on sternopleonal cavity]. A, B intestinal region and posterior margin of carapace $\mathbf{C}, \mathbf{D}$ male thoracic sternum and pleon (somite 6 damaged and telson missing in D) $\mathbf{E}, \mathbf{F}$ outer view of right chela.

Small specimens have proportionately shorter meri of the chelipeds although in all other aspects, the structures are similar (Figs 7B, F, 11B).

Colour. The fresh holotype of $P$. stellatus was a dull orange throughout, with some of the large posterior tubercles white; the distal two-thirds of fingers bright orange and basal third cream (Fig. 1E). The ventral surfaces are generally dirty white to light brown (Fig. 1F). A relatively larger fresh specimen of P. agariciferus (18. $1 \mathrm{~mm}$ carapace width) was figured by Galil and $\mathrm{Ng}$ (2007: fig. 3B) and its colour was similar to that 

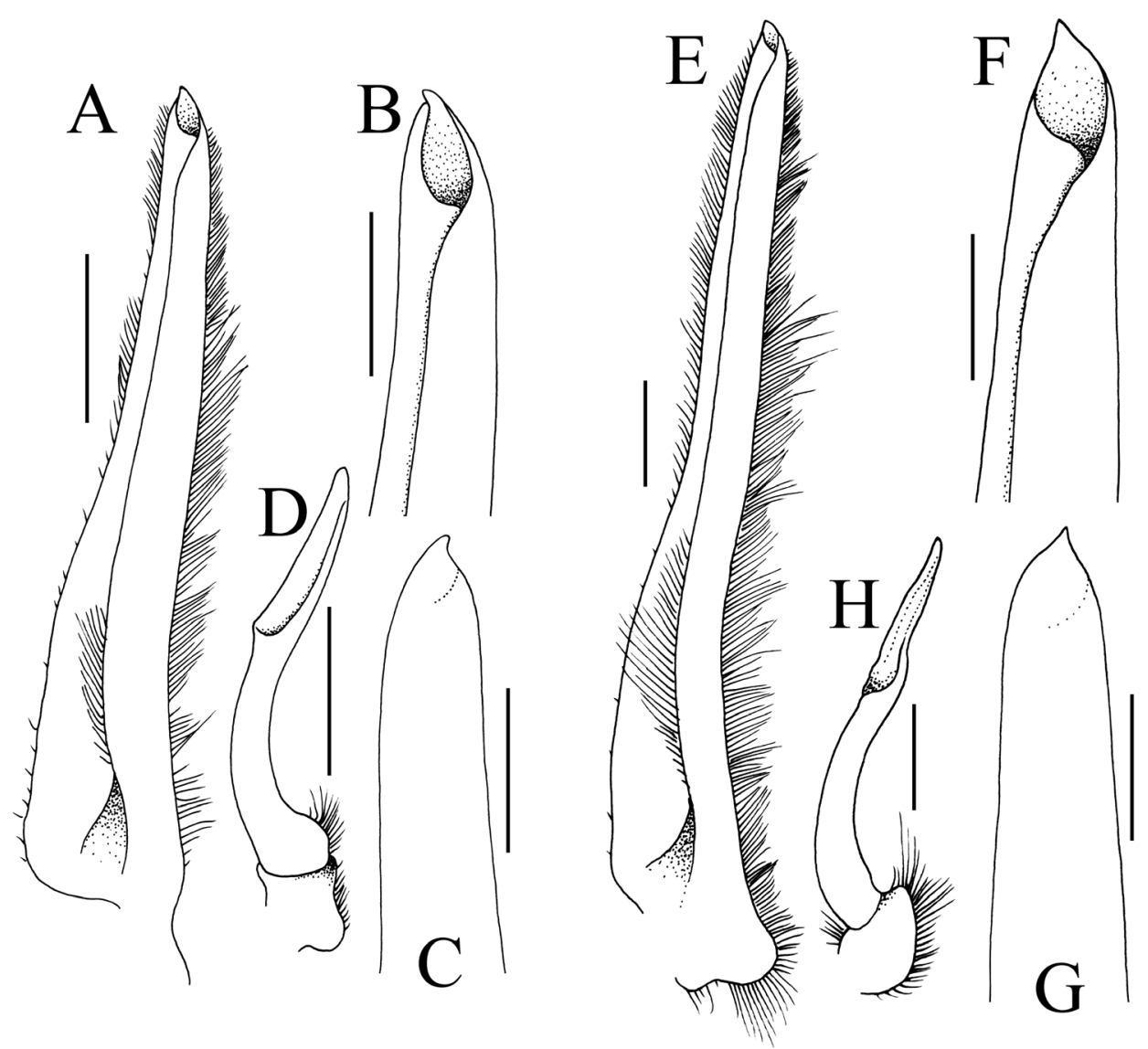

Figure 13. Gonopods. A-D Pariphiculus agariciferus Ihle, 1918, male $(15.8 \times 15.0 \mathrm{~mm})$ (ZRC), Philippines E-H P. stellatus sp. n., holotype male $(27.7 \times 24.5 \mathrm{~mm}$ ) (ASIZ 75485), Taiwan. A-C, E-G left G1 D, H left G2. Scale bars A, E, D, H $1.0 \mathrm{~mm}$; B, C, F, G $0.5 \mathrm{~mm}$.

of $P$. stellatus, being orange throughout. A smaller male specimen from Taiwan $(12.9 \times$ $12.3 \mathrm{~mm}$, ASIZ 75113), however, had most of the carapace and chelipeds white and pale orange (Shih et al. in press). A similar sized male from Vanuatu $(11.9 \times 12.1 \mathrm{~mm}$, ZRC 2009.471) had a similar colour pattern as the Taiwan specimen except that the colour is more intense (Fig. 1D)

Etymology. The species is named after the prominent asteriform or "star-like" mushroom-shaped tubercles and granules on the carapace and chelipeds.

Remarks. The large specimen from Taiwan is interesting as it is almost identical with a large female specimen measuring $36.2 \times 30.3 \mathrm{~mm}$ figured by Ikeda (1998: 84) from Sagami Bay which he identified as "Pariphiculus sp." Ng (1999: 718), in his review of the book, noted that this was almost certainly a new species although he incorrectly suggested it may be a species of Parilia Wood-Mason in Wood-Mason \& Alcock, 1891, instead. Examination of the present Taiwanese specimen suggests it is 
close to Pariphiculus agariciferus Ihle, 1918, a species known from Indonesia, Japan, Philippines, Taiwan, South China Sea and Vanuatu (Ihle 1918: 250; Balss 1922: 131; Yokoya 1933: 129; Sakai 1937: 131; Sakai 1965: 43; Serène and Vadon 1981:124; Sakai 1976: 104; Chen 1989: 231; Tan 1996: 1023; Komatsu et al. 2005: 106; Galil and Ng 2007: 87; Galil and Ng 2010: 143; Ng et al. 2008: 37; Shih et al. in press). The size of the Taiwanese (and Ikeda's Japanese) specimen, however, is much larger (almost twice) that what is known for $P$. agariciferus which averages $15-20 \mathrm{~mm}$ in carapace width. The Taiwanese specimen differs from typical $P$. agariciferus in a number of carapace, cheliped, male pleonal and G1 characters that suggests that it is a different taxon, but its large size makes comparisons difficult.

Fortunately, there is a good series of specimens of what had been identified as " $P$. agariciferus" from Philippines and Vanuatu by Galil and Ng (2007, 2010), as well as additional material in the ZRC not reported by them. While the majority of the specimens are $P$. agariciferus s. str., there are several specimens mixed among this material (cf. Galil and Ng 2007) that are clearly conspecific with the Taiwan specimen. This includes a small male specimen of the new species which allows for size-equivalent comparisons between the two taxa to be made. We can now be confident that the present Taiwanese male, Ikeda's (1998) specimen, and some of the Philippine material represent a new species, here named Pariphiculus stellatus sp. n.

Pariphiculus agariciferus Ihle, 1918, is a smaller species, with all specimens less than $22 \mathrm{~mm}$ in carapace length. The holotype male from seas around Timor and Rotti islands in Indonesia measured $9.0 \times 9.3 \mathrm{~mm}$ (not measured to tip of spines). The carapace of the holotype male has all the lateral spines relatively slender and long, all of which are covered with additional spinules and tubercles; with the tubercles and granules on the carapace and chelipeds mushroom-shaped (Fig. 4A). A slightly larger male from Vanuatu has a very similar in carapace morphology (Fig. 4B). These characters are almost certainly juvenile features; the small Vanuatu specimen is still subadult, with the gonopods poorly chitinised; and the holotype male is probably a young individual as well. In the larger male specimens from the Philippines, Taiwan and Vanuatu, the lateral spines (including those on the posterior carapace margin) are relatively shorter and stouter (Figs 4C-F, 6AF). The ambulatory meri and dactyli of the smallest specimens are also proportionately more slender and elongate (Fig. 4A, B). As specimens get larger (regardless of sex), the carapace becomes proportionately wider and rounder, and the spines shorter and blunter (Fig. 4C-F). The ambulatory meri and dactyli of these larger specimens are also relatively stouter and shorter (Fig. 4C-F). As the specimens increase in size, the tops of the mushroom-shaped tubercles on the carapace and chelae also become more mushroom-shaped, with the margins more gently serrated and distinctly asteriform (Figs 4C-F, 6A-F).

Pariphiculus stellatus sp. n. can be distinguished from P. agariciferus in having the gastric and branchial regions of the carapace proportionately less inflated (Figs 8A, G, $11 \mathrm{D}, \mathrm{F}$ ) (vs. prominently inflated in frontal view in P. agariciferus; cf. Fig. 11C, E); the tubercles on the carapace, chelipeds and third maxillipeds are prominently mushroomshaped but relatively lower, with the tops of the large tubercles distinctly asteriform 
(Figs 8A-C, G, 9A, B, 11D, F, 12B) (vs. tubercles on the carapace are relatively higher and mushroom-shaped, with the margins of the tops of the tubercles uneven but not distinctly asteriform in P. agariciferus; cf. Figs 5A, B, 6A-F, 11C, E, 12A); in lateral view, the surface behind the postfrontal region is gently concave, forming a shallow depression (Fig. 11F) (vs. area behind postfrontal region deeply concave, with a marked depression between frontal and gastric regions in P. agariciferus; cf. Fig. 11E); the suborbital tubercle is relatively low, not protruding and not conspicuous (Figs 8A, G, 9C, 11D) (vs. suborbital tubercle is large and prominently protrudes anteriorly in P. agariciferus; cf. Fig. 11C); the palms of the chelae are relatively long, slender with the fingers gently curved (Figs 9E-H, 12F) (vs. palms relatively short, swollen with the fingers distinctly curved in P. agariciferus; cf. Figs 6G-J, 12C); the dorsal margin of the dactylus and ventral margin of the pollex of the chela is lined with low granules, never serrated (Figs $9 \mathrm{E}-\mathrm{H}, 12 \mathrm{~F}$ ) (vs. non-cutting margins of dactylus and pollex with prominent sharp and/ or mushroom-shaped granules, appears serrated in P. agariciferus; cf. Figs 6G-J, 12C); the tubercles and granules on the surface of the male and female pleons are larger, tend to be fused, forming semi-eroded structures (Figs 8D, E, H, 9D, 12D) (vs. tubercles and granules tend to be smaller, discrete and packed in P. agariciferus; cf. Figs 5C-H, $12 \mathrm{C}$ ); the male telson is proportionately shorter, even in small specimens (Figs $8 \mathrm{D}, \mathrm{E}$, $\mathrm{H}, 12 \mathrm{D}$ ) (vs. male telson more elongate in P. agariciferus; cf. Figs 5C-F, 12C); and the G1 is relatively longer and more slender (Fig. 13E) (vs. G1 proportionately stouter and shorter in P. agariciferus; cf. Fig. 13A). It is important to note also that the single male specimen of $P$. stellatus sp. n. (Figs 11B-F, 12B-F) similar in size to adult $P$. agariciferus (Figs 11A, C, E, 12A, C, E) is still subadult, with the G1 soft and not well developed.

All the specimens of $P$. stellatus sp. $n$. have been collected by tangle nets in Taiwan and the Philippines. This is also true for all the P. agariciferus collected from the Philippines, with only a few specimens obtained by trawls (e.g. those in Vanuatu and Taiwan). The material from the Philippines was collected from deeper waters along steep cliffs, areas which can neither be sampled by divers, trawls or dredges ( $\mathrm{Ng}$ et al. 2009). These heretofore rare species almost certainly prefer such inaccessible habitats and are thus rarely collected by dredges and trawls (see Mendoza et al. 2010).

Distribution and depth. Ikeda's (1998) Japanese specimen was collected from $180-200 \mathrm{~m}$ of water off Nagai in Sagami Bay. The holotype male from Taiwan was obtained from a depth of $170 \mathrm{~m}$, with the series from the Philippines collected from $80-140 \mathrm{~m}$.

\section{Acknowledgements}

This study was partially sponsored by the Fisheries Agency, Council of Agriculture, Executive Yuan, R.O.C. (106AS-10.2.1-FA-F1). We are grateful to Bella Galil, Hironori Komatsu, and Sammy De Grave for their many constructive comments. Thanks are also due to Cheng Anyi (ASIZ) for her help with the manuscript. 


\section{References}

Alcock A (1896) Materials for a carcinological fauna of India. No. 2. The Brachyura Oxystoma. Journal of the Asiatic Society of Bengal 65(2): 134-296. [pls 6-8]

Alcock A (1899) An account of the deep-sea Brachyura collected by the marine survey ship "Investigator". Trustees of the Indian Museum, Calcutta, 85 pp. [4 pls.]

Alcock A (1900) Materials for a carcinological fauna of India. No. 5. Brachyura Primigenia or Dromiacea. Journal of the Asiatic Society, Bengal 1899(1900) 68: 123-169.

Balss H (1922) Ostasiatische Decapoden. III. Die Dromiaceen, Oxystomen und Parthenopiden. Archiv für Naturgeschichte 88A(3): 104-140. [figs 1-9]

Chen H (1989) Leucosiidae (Crustacea, Brachyura). In: Forest F (Ed.) Résultats des Campagnes MUSORSTOM, Volume 5. Mémoires du Muséum National d'Histoire Naturelle, Paris (A) 144: 181-263.

Davie PJF, Guinot D, Ng PKL (2015) Anatomy and functional morphology of Brachyura.. In: Castro P, Davie PJF, Guinot D, Schram FR, von Vaupel Klein JC (Eds) Treatise on Zoology - Anatomy, Taxonomy, Biology. The Crustacea. Volume 9C-I. Decapoda: Brachyura (Part 1), 11-163. https://doi.org/10.1163/9789004190832_004

Galil BS, Ng PKL (2007) Leucosiid crabs from Panglao, Philippines, with descriptions of three new species (Crustacea: Decapoda: Brachyura). Raffles Bulletin of Zoology, Supplement 16: 79-94.

Galil BS, Ng PKL (2010) On a collection of calappoid and leucosioid crabs (Decapoda, Brachyura) from Vanuatu, with description of a new species of Leucosiidae. In: Castro P, Davie PJF, Ng PKL, Richer de Forges B (Eds) Studies on Brachyura: a homage to Danièle Guinot. Crustaceana Monographs 11: 139-152.

Ihle JEW (1918) Die Decapoda Brachyura der Siboga-Expedition. III. Oxystomata: Calappidae, Leucosiidae, Raninidae. Siboga Expeditie 39b2: 1-322.

Ikeda H (1998) The Deep-Sea Crabs of Sagami Bay. Hayama Shiosai Museum, Kanagawa, Japan, 180 pp.

Komatsu H, Manuel MR, Takeda M (2005) A small collection of leucosiid crabs (Crustacea; Decapoda; Brachyura) from Balicasag Island, Bohol, Philippines. Species Diversity 10: 105-123.

Marumura M, Kosaka A (2003) Catalogue of the brachyuran and anomuran crabs donated by the late Mr. Seiji Nagai to the Wakayama Prefectural Museum of Natural History. Wakayama Prefectural Museum of Natural History, Kainan, 73 pp.

McLay CL (1999) Crustacea Decapoda: Revision of the family Dynomenidae. In: Crosnier A (Ed.) Résultats des Campagnes MUSORSTOM Volume 20. Mémoires du Muséum national d'Histoire naturelle 180: 427-569. [figs 1-40]

McLay CL, Ng PKL (2005) On a collection of Dromiidae and Dynomenidae from the Philippines, with description of a new species of Hirsutodynomene McLay, 1999 (Crustacea: Decapoda: Brachyura). Zootaxa 1029: 1-30. https://doi.org/10.11646/zootaxa.1029.1.1

Mendoza JCE, Naruse T, Tan SH, Chan T-Y, Richer de Forges B, Ng PKL (2010) Case studies on decapod crustaceans from the Philippines reveal deep, steep underwater slopes as prime habitats for 'rare' species. Biological Conservation 19: 575-586. https://doi.org/10.1007/ s10531-009-9744-x 
Milne-Edwards A (1880) Études préliminaires sur les Crustacés, 1 ère Partie. In: Reports on the results of dredging under the supervision of Alexander Agassiz, in the Gulf of Mexico, and the Caribbean Sea, 1877, 1878, 1879, by the U. S. coast survey steamer "Blake". Lieut.Commander C. D. Sigsbee, U.S.N., and Commander J. S. Bartlett, U.S.N. commanding. Bulletin of the Museum of Comparative Zoology, Harvard 8(1): 1-68. [pls. 1, 2]

MOJ (Ministry of Justice, Taiwan) (2014) Laws and Regulations Database of The Republic of China. Management approach to fishing vessels engaging in coral fisheries in Taiwan. Dated 26 September 2014. http://law.moj.gov.tw/LawClass/LawOldVer.aspx?Pcode=M00 50038\&LNNDATE=20140210\&LSER=001

Nagai S (1989) Brachyuran fauna of Wakayama Prefecture II, Nankiseibutu 31(1): 39-44.

Ng PKL (1999) Book review: The Deep-Sea Crabs of Sagami Bay. H. Ikeda, 1998. Hayama Shiosai Museum, Kanagawa, Japan. Crustaceana 72(7): 717-718.

Ng PKL, Guinot D, Davie PJF (2008) Systema Brachyurorum: Part I. An annotated checklist of extant brachyuran crabs of the world. Raffles Bulletin of Zoology, Supplement 17: $1-286$.

Ng PKL, Mendoza JCE, Manuel-Santos M (2009) Tangle net fishing, an indigenous method used in Balicasag Island, central Philippines. Raffles Bulletin of Zoology, Supplement 20: $39-46$.

Ortmann AE (1892) Die Abtheilungen Hippidea, Dromiidea und Oxystomata. Die Decapoden-Krebse des Strassburger Museums, mit besonderer Berücksichtigung der von Herrn Dr. Döderlein bei Japan und bei den Liu-Kiu-Inseln gesammelten und zur Zeit im Strassburger Museum aufbewahrten Formen. Theil V [= Part V]. Zoologische Jahrbücher, Abtheilung für Systematik Geographie und Biologie der Thiere 6(4): 532-588. [pl. 26]

Sakai T (1937) Studies on the Crabs of Japan. II. Oxystomata. Science Reports of the Tokyo Bunrika Daigaku, Section B, 3 (Supplement 2): 67-192. [figs 1-45, pls 10-19, Table I]

Sakai T (1965) The Crabs of Sagami Bay, collected by His Majesty the Emperor of Japan. Tokyo, Maruzen Co., 206 pp. [figs 1-27 (English text), pls 1-100, pp 1-92 (Japanese text), pp 1-26 (references and index in English), pp 27-32 (index in Japanese), 1 map]

Sakai T (1976) Crabs of Japan and the adjacent seas. Tokyo, Kodansha Ltd. [3 volumes: (1) English text, xxxix + 773 pp, figs, 1-379; (2) Plates, 16 pp., pls 1-251; (3) Japanese text, 461 pp, figs 1-2]

Serène R, Vadon C (1981) Crustacés Décapodes. Brachyoures. Liste préliminaire, description de formes nouvelles et remarques taxonomiques. Résultats des Campagnes MUSORSTOM, 1. Philippines (18-28 Mars 1976). Memoires ORSTOM, No. 91 1981: 117-140. [pls 1-4] Shih Y-J, Ho H-P, Jeng M-S (in press) Two new records of the leucosioid genus Pariphiculus (Alcock, 1896) from Taiwan (Decapoda, Brachyura, Iphiculidae). Crustaceana.

Tan CGS (1996) Leucosiidae of the Albatross expedition to the Philippines, 1907-1910 (Crustacea: Brachyura: Decapoda). Journal of Natural History 30: 1021-1058. https://doi. org/10.1080/00222939600770551

Tan CGS, Ng PKL (1995) A revision of the Indo-Pacific genus Oreophorus Rüppell, 1830 (Crustacea: Decapoda: Brachyura: Leucosiidae). In: Richer de Forges B (Ed.) Les fonds meubles des lagons de Nouvelle-Calédonie (Sédimentologie, Benthos), Etudes \& Thèses, Volume 2, ORSTOM, 101-205. [pls 1-16] 
Tu T-H, Dai C-F, Jeng M-S (2012) Precious corals (Octocorallia: Coralliidae) from the northern West Pacific region with descriptions of two New Species. Zootaxa 3395: 1-17.

Yokoya Y (1933) On the Distribution of Decapod Crustaceans inhabiting the Continental Shelf around Japan, chiefly based upon the Materials collected by S. S. Sôyô-Maru, during the Year [sic] 1923-1930. Journal of the College of Agriculture, Tokyo Imperial University 12(1): 1-226. [figs 1-71] 